\title{
Ecological services of agroforestry systems in selected upland farming communities in the Philippines
}

\author{
ROMNICK S. BALITON ${ }^{1}$, LEILA D. LANDICHO ${ }^{2, \vartheta}$, ROWENA ESPERANZA D. CABAHUG ${ }^{2}$, \\ ROSELYN F. PAELMO ${ }^{3}$, KENNETH A. LARUAN ${ }^{4}$, RAMIL S. RODRIGUEZ ${ }^{5}$, ROBERTO G. VISCO ${ }^{2}$, \\ ARNOLD KARL A. CASTILLO ${ }^{2}$ \\ ${ }^{1}$ Institute of Renewable Natural Resources, College of Forestry and Natural Resources, University of the Philippines Los Banos. Laguna, Philippines \\ ${ }^{2}$ Institute of Agroforestry, College of Forestry and Natural Resources, University of the Philippines Los Banos. Laguna, Philippines. \\ "email: dlandicho@gmail.com \\ ${ }^{3}$ Institute of Crop Science, College of Agriculture and Food Science, University of the Philippines Los Banos, Laguna, Philippines \\ ${ }^{4}$ College of Forestry, Benguet State University. La Trinidad, Benguet, Philippines \\ ${ }^{5}$ College of Forestry, Nueva Vizcaya State University. Bayombong, Nueva Vizcaya, Philippines
}

Manuscript received: 24 September 2019. Revision accepted: 23 January 2020.

\begin{abstract}
Baliton RS, Landicho LD, Cabahug RED, Paelmo RF, Laruan KA, Rodriguez RS, Visco RG, Castillo AKA. 2020. Ecological services of agroforestry systems in selected upland farming communities in the Philippines. Biodiversitas 21: 707-717. A study was conducted in three selected upland farming communities in Nueva Vizcaya, Benguet and Quezon, Philippines to assess the ecological services of agroforestry systems. Results showed that alley cropping was the dominant agroforestry system in Nueva Vizcaya, while vegetable-based and coffee-based multistorey systems were found prevailing in Benguet and Quezon provinces. Agrobiodiversity assessment revealed that the values of Shannon-Wiener diversity index of agroforestry systems in the three study sites were considered to be low to moderate, ranging from 2.21 to 2.71 . This validates that the number of individuals per species in the agroforestry landscape was not evenly distributed. The means of biomass in the three study sites, ranging from 106.22-127 tons ha ${ }^{-1}$, were higher than that of agroforestry systems (102.80 tons $\left.\mathrm{ha}^{-1}\right)$ in the Philippines. The agroforestry systems in Nueva Vizcaya had the largest carbon stock of

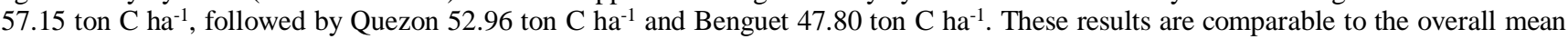
of carbon stock of tree plantations (59.0 ton $\left.\mathrm{C} \mathrm{ha}^{-1}\right)$ and higher than that of agroforestry systems in the Philippines, i.e., 45.4 ton $\mathrm{C}$ ha ${ }^{-1}$. Therefore, this article argues that the different agroforestry systems provide ecological services in the upland farming communities in the Philippines.
\end{abstract}

Keywords: Agrobiodiversity, alley cropping, biomass, carbon stock, multistorey system

\section{INTRODUCTION}

Agroforestry is a dynamic, ecologically-based natural resource management system that deliberately combines woody perennials with herbaceous crops and/or animals, either in some forms of spatial arrangement or temporal sequence on the same land, with the aim of diversifying and sustaining production for increased social, economic and environmental benefits (Leakey cited in World Agroforestry Centre 2007; Lundgren and Raintree 1983). The more tangible contributions of agroforestry are highly recognized by the smallholder farmers in the Philippines, particularly in addressing their socioeconomic needs (Tolentino et al. 2010, IAF 2003). The intangible and indirect contributions of agroforestry should equally be recognized especially that environmental issues such as climate change and global warming are at their peak in recent years. The ecological services of agroforestry should, therefore, be highlighted in the research and development endeavors.

Jose (2009) proposed the need to fully explore the role of agroforestry as an environmentally benign and ecologically sustainable alternative to traditional farming in an era of environmental consciousness and ecological sustainability. Furthermore, Jose (2009) argues that there has been a recent accumulation of evidence that supports the ecosystem services of agroforestry systems and practices in the tropical and temperate regions. In South Africa, for instance, Sileshi et al (2007) reviewed the studies conducted earlier and concluded that agroforestry practices provide provisioning services such as food, source of energy and fodder, regulatory services such as microclimatic modification, erosion control mitigation of desertification, carbon sequestration, and pest control, and supporting services such as soil fertility improvement, biodiversity conservation and pollination in the Miombo Eco-Region. Murthy et al. (2013) claimed that trees in agroforestry systems are an important resource providing products and services to society. Specifically, trees contribute to stabilizing the atmospheric carbon dioxide concentration and reducing the carbon emissions or increasing the carbon sink in different land-use systems.

This article highlights the results of the study which assessed the ecological services of agroforestry systems in the three selected upland farming communities in Nueva Vizcaya, Benguet, and Quezon, Philippines. 


\section{MATERIALS AND METHODS}

\section{Study sites}

The study was conducted from January to November 2016 in three upland farming communities, namely: (1) Barangay Ba-ayan in Tublay, Benguet, (2) Barangay Masoc in Bayombong, Nueva Vizcaya, and (3) Barangay Concepcion Banahaw in Sariaya, Quezon (Figure 1). These communities represent different climatic types based on the 2001 Revised Corona's Climatic Classification in the Philippines. The Province of Nueva Vizcaya is divided into Type 1 and Type 2 climates, with Quezon belonging to Type 1, while Benguet to Type 3. Type 1 is described as having two pronounced seasons, the dry one from November to April and the wet one during the rest of the year with the maximum rain period happening from June to September. Type 2 has no dry month or season with a very pronounced maximum rain period from December to February. Minimum monthly rainfall occurs from March to May. Type 3 has no pronounced maximum rain period, with a short dry season lasting from one to three months, either from December to February or from March to May. This climate type resembles Type 1 since it has a short dry season.
Field surveys, interviews and focus group discussion (FGD)

Transect walks were done to identify the vegetation and other land uses, including the type of agroforestry systems being practiced at various elevations of the upland areas in the three study sites. Direct interviews with the farmerrespondents were administered to gather other primary data related to agricultural production activities. A total of 89 , 76 and 59 farmer-respondents were selected in the upland farming communities in Benguet, Nueva Vizcaya, and Quezon, respectively, using simple random sampling. FGD provided a venue in identifying the agroforestry systems being practiced in the three communities, analyzing the strengths and weaknesses of the agroforestry systems, and, identifying strategies that would address the issues and problems on agroforestry farm management.

\section{Plot establishment}

A circular plot with a radius of $8.9 \mathrm{~m}\left(249 \mathrm{~m}^{2}\right)$ was laid out in each agroforestry system. All trees, palms and banana species inside the circular plot were identified and recorded. Additional four $1 \mathrm{~m} \times 1 \mathrm{~m}$ subplots (for agrobiodiversity) and $0.5 \mathrm{~m} \times 0.5 \mathrm{~m}$ (for carbon stock) were laidout inside the circular plots for the undergrowth plants and litter. All trees with DBH less than $5 \mathrm{~cm}$ were recorded together with other forms of plants encountered inside the $1 \mathrm{~m} \times 1 \mathrm{~m}$ subplots, while litter and other vegetation were harvested and collected in $0.5 \mathrm{~m}$ by $0.5 \mathrm{~m}$ subplots.

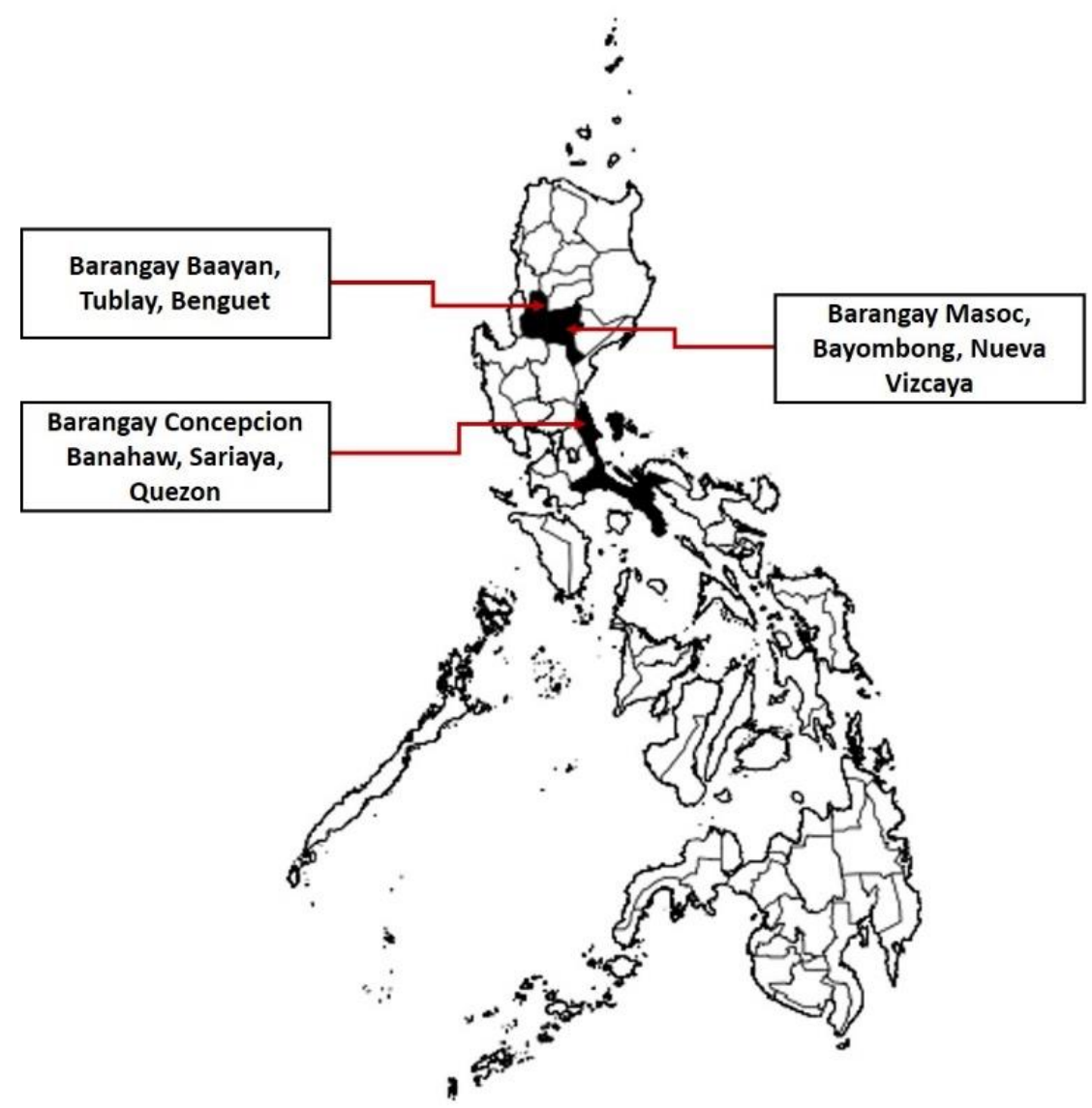

Figure 1. The study site in (1) Barangay Ba-ayan in Tublay, Benguet, (2) Barangay Masoc in Bayombong, Nueva Vizcaya, and (3) Barangay Concepcion Banahaw in Sariaya, Quezon, Philippines 


\section{Measurement of biometrics and ecological parameters} Agrobiodiversity Assessment

All the trees, palms and bananas inside the circular plots were identified and recorded. Their taxonomic names and families were also determined using available references. Diameter at breast height $(\mathrm{DBH}-1.3 \mathrm{~m}$ above the soil surface) greater than or equal to $5 \mathrm{~cm}$ were measured. For palms and bananas that are not covered by the standard diameter-biomass relationship, in addition to $\mathrm{DBH}$, the total height was also measured and recorded. Basal area (Equation 1) was determined using diameter which then was used for volume computation (Equation 1.1), as shown below:

Equation 1 and Equation 1.1.:

$$
\begin{aligned}
& \text { BasalArea }\left(m^{2} / h a\right)=(0.007854) *(D B H)^{2} \\
& \text { TreeVolume }=(B A) *(M H)
\end{aligned}
$$

Crown area/canopy cover was measured using Equation 2. The average radius of the canopy used in calculating the area was determined by measuring the crown length in four cardinal directions (i.e. NEWS).

\section{Equation 2:}

$$
\text { Crown Area }\left(m^{2}\right)=(\pi) *(\text { Averagecanopyradius })^{2}
$$

The Importance value (IV) of each tree species was then determined to give an estimate of its influence towards the agroforestry farms sampled and in the entire watershed area. The IV was computed through the relative frequency, relative density, and relative dominance of each tree species. The larger the IV, the more dominant is the species in a particular locality. The following equations were used to determine the biometrics and ecological parameters used in computing for the IV

Equations 3-9 were used to determine the biometrics and ecological parameters mentioned:

Equation 3:

Density $=\frac{\text { Total Number of tree individual counted per species }}{\text { Total Area Sampled }}$

Equation 4:

Relative Density $=\frac{\text { Total } \text { Number of tree individual counted per } \text { species }}{\text { Total Number of all Species }} * 100$

Equation 5:

Species Coverage $=(0.7854) *(D B H)^{2}$ or Basal Area

Equation 6:

Relative Dominance $=\frac{\text { Dominance of a Species }}{\text { Total Dominance of all Species }} * 100$

Equation 7:

Species Frequency $=\frac{\text { Number of Plots species occur }}{\text { Total Number of Plots }} * 100$

Equation 8:

Relative Frequency $=\frac{\text { Frequency of a species }}{\text { Total Frequency of all Species }} * 100$

Equation 9:

Importance Value $=$ Relative Density + Relative Dominance + Relative Frequency
Meanwhile, Shannon-Wiener diversity index (H') was used to estimate biological diversity of an area. It could be used to assess the variation of population of different species in an ecosystem. In addition, Pielou's evenness index $(\mathrm{J})$ serves as a measure of the relative abundance of the different species that make up the plant community. Equation 10 shows how H' was computed while species evenness was measured using Equation 11.

$$
\begin{aligned}
& \text { Equation 10: } \\
& \qquad \begin{array}{l}
\mathrm{S} \\
\mathrm{H}^{\prime}=\sum_{\mathrm{i}=1}-\left(\mathrm{P}_{\mathrm{i}} * \ln \mathrm{P}_{\mathrm{i}}\right)
\end{array}
\end{aligned}
$$

Where:

$\mathrm{H}^{\prime}=$ Shannon-Wiener Diversity Index

$\mathrm{P}_{\mathrm{i}}=$ fraction of the entire population made up of species $\mathrm{i}$

$\mathrm{S}=$ numbers of species encountered/species richness

$\sum=$ sum from species 1 to species $\mathrm{S}$

Note: The power to which the base e (e = $2.718281828 \ldots . . .$. .) must be raised to obtain a number is called the natural logarithm (ln) of the number.

Equation 11:

$$
\mathrm{J}=\mathrm{H}^{\prime} / \ln (\mathrm{S})
$$

Where:

$\mathrm{J}=$ Pielou's Evenness Index

$\mathrm{H}^{\prime}=$ Shannon's diversity index

$\ln (\mathrm{S})$ - natural logarithm of species richness

The index was analyzed using the classification scheme proposed by Fernando et al. (1998) (Table 1).

\section{Carbon stock assessment}

The carbon stock of different agroforestry systems in the study sites was measured using the biomass estimation method. Tree biomass was calculated using Brown's (1997) allometric equation (Table 2), which measures the total above-ground biomass (TAGB) of standing woody perennials or living trees with $\mathrm{DBH}$ of $5 \mathrm{~cm}$ and above. The biomass of palms was calculated using the equation from a study of Frangi and Lugo (1985) as cited in Roshekto et al (1999). For the banana biomass, the allometric equation developed by Marquez (1999) as cited by Roshekto et al (1999) was used. Table 2 shows the allometric equations that were used in biomass estimation.

Table 1. Classification scheme for the Shannon Diversity Index (Fernando et al. 1998).

\begin{tabular}{ll}
\hline Relative values & $\begin{array}{l}\text { Shannon-Wiener diversity } \\
\text { index }\left(H^{\prime}\right)\end{array}$ \\
\hline Very High & 3.50 and above \\
High & $3.00-3.49$ \\
Moderate & $2.50-2.99$ \\
Low & $2.0-2.49$ \\
Very Low & 1.99 and below \\
\hline
\end{tabular}


Table 2. Allometric equations for biomass estimation.

\begin{tabular}{llllll}
\hline Species & Biomass pool & Equation & DBH $(\mathbf{c m})$ & $\begin{array}{l}\text { No. } \\
\text { trees }\end{array}$ & $\begin{array}{c}\text { of } \\
\text { Adjusted R }\end{array}$ \\
\hline Tropical Moist & Above-ground & $\mathrm{Y}=\exp \left\{2.134+2.530^{*} \ln (\mathrm{D})\right\}$ & $5-148$ & 170 & 0.97 \\
Tropical Forests & Below-ground & $\mathrm{Y}=0.15^{*}(\mathrm{AGB})$ & $>5$ & 151 & 0.84 \\
Palms & -- & $\mathrm{Y}=4.5+7.7 * \mathrm{H}$ & -- & 0.90 \\
Banana & -- & $\mathrm{Y}=0.30^{*} \mathrm{D}^{\wedge} 2.13$ & -- & -- & -- \\
\hline
\end{tabular}

Note: TAGB $=$ total above-ground biomass in kg/tree; $\exp \{\ldots\}=$ "raised to the power of"; $\ln =$ "natural $\log$ of $\{\ldots\}$; DBH = Diameter at breast height in $\mathrm{cm} ; H=$ Height

Total tree biomass (Equation 13) and carbon (C) stored (Equation 6) were then calculated using the following equations:

\section{Equation 13:}

Tree biomass $=$ Tree biomass $(\mathrm{Mg}) /$ Sample area in hectare $C$ stored $(\mathrm{MgC}$ ha- 1$)=$ Tree biomass density $* C$ content

On the other hand, the carbon stock of herbaceous or living non-perennial crops and litter found in the soil surface was calculated by first computing for the total dry weight (Equation 14), and multiplying that by a set C content to get the total carbon stored (Equation 15).

Equation 14:

Total Dry Weight $\left(\mathrm{kg} \mathrm{m}^{-2}\right)=\frac{\text { Total Fresh Weight }(\mathrm{kg}) * \text { Subsample Dryweight }(\mathrm{g})}{\text { Subsample Fresh Weig ht }(\mathrm{g}) * \text { Sample Area }\left(\mathrm{m}^{2}\right)}$

Equation 15:

C Stored $\left(M g C h a^{-1}\right)=$ Total Dry Weight $* C$ Content

Lastly, below-ground biomass of trees and other perennials was obtained using the default value proposed by Delaney and Roshetko (1999) at 15 percent of the total above-ground biomass. Field data collection, preparation, and analysis were conducted following the protocol proposed by MacDicken (1997) of the Winrock International Institute for Agricultural Development.

\section{RESULTS AND DISCUSSION}

\section{Socioeconomic characteristics of upland farmers in the study areas}

The socio-demographic characteristics of the sampled farmers in the study are summarized in Table 3 . The survey revealed that farming was dominated by men with 66 percent of the respondents. There were, however, a comparable number of women engaged in agriculture in Ba-ayan, Tublay, Benguet. Majority of the respondents were married (83\%), with household size ranging from 4-6 members, as reported by 50 percent of the respondents. Meanwhile, majority of the respondents were between the ages of 30-60, with most of the farmers within the range of 41-50 (29\%). This suggests that most upland farmers were still in the productive age. In terms of education, most of them only reached or finished elementary school. This mirrors the results of earlier studies (Landicho et al. 2015; Visco et al. 2012) that most rural farmers in the Philippines have low level of formal education, probably because of their geographical location, which is often far from school facilities, as well as their personal choices. It is noteworthy that majority of the farmer-respondents in all three sites were natives in their respective upland communities (73\%). As such, they share the same symbols and meanings, which could facilitate group activities and collaboration, and foster information exchange. This could have helped facilitate the formation of social organizations in the communities, as shown in the result that majority of the farmer-respondents were members of farmers' organizations $(78 \%)$.

Table 3. Sociodemographic characteristics of farmer-respondents in the three study sites.

\begin{tabular}{|c|c|c|c|c|c|}
\hline & Freq & uency $(n=$ & =215) & & \\
\hline $\begin{array}{l}\text { Socio-demographic } \\
\text { characteristics }\end{array}$ & $\begin{array}{c}\text { Nueva } \\
\text { Vizcaya } \\
(n=76)\end{array}$ & $\begin{array}{c}\text { Quezon } \\
(\mathbf{n}=50)\end{array}$ & $\begin{array}{c}\text { Benguet } \\
(\mathrm{n}=\mathbf{8 9}\end{array}$ & Total & $\%$ \\
\hline Sex & & & & & \\
\hline Male & 48 & 45 & 48 & 141 & 66 \\
\hline Female & 28 & 5 & 41 & 74 & 34 \\
\hline Civil status & & & & & \\
\hline Single & 7 & 1 & 12 & 20 & 9 \\
\hline Married & 64 & 47 & 67 & 178 & 83 \\
\hline Separated & 1 & 0 & 1 & 2 & 1 \\
\hline Widow/er & 4 & 2 & 9 & 15 & 7 \\
\hline Household size & & & & & \\
\hline $1-3$ & 32 & 8 & 20 & 60 & 28 \\
\hline 4-6 & 33 & 33 & 44 & 110 & 51 \\
\hline$>6$ & 11 & 9 & 25 & 45 & 21 \\
\hline Age range & & & & & \\
\hline$<30$ & 10 & 2 & 3 & 15 & 7 \\
\hline $30-40$ & 26 & 12 & 15 & 53 & 25 \\
\hline $41-50$ & 21 & 16 & 27 & 64 & 30 \\
\hline $51-60$ & 11 & 12 & 29 & 52 & 24 \\
\hline$>60$ & 8 & 8 & 15 & 31 & 14 \\
\hline Level of education & & & & & \\
\hline No formal education & 1 & 1 & 2 & 4 & 2 \\
\hline Elementary level & 16 & 9 & 11 & 36 & 17 \\
\hline Elementary graduate & 12 & 26 & 32 & 70 & 33 \\
\hline High school level & 13 & 2 & 12 & 27 & 13 \\
\hline High school graduate & 15 & 7 & 18 & 40 & 19 \\
\hline College level & 4 & 1 & 7 & 12 & 6 \\
\hline College graduate & 7 & 0 & 7 & 14 & 7 \\
\hline $\begin{array}{l}\text { Vocational course } \\
\text { graduate }\end{array}$ & 8 & 4 & 0 & 12 & 6 \\
\hline Migration & & & & & \\
\hline Number of migrants & 48 & 6 & 5 & 59 & 27 \\
\hline Number of natives & 28 & 44 & 84 & 156 & 73 \\
\hline Membership to social & ganizatio & & & & \\
\hline $\begin{array}{l}\text { Member of an } \\
\text { organization }\end{array}$ & 44 & 44 & 80 & 168 & 78 \\
\hline Non-member & 32 & 6 & 9 & 47 & 22 \\
\hline
\end{tabular}


Table 4. Economic conditions of the farmer-respondents in the three study sites.

\begin{tabular}{|c|c|c|c|c|c|}
\hline \multirow{2}{*}{$\begin{array}{c}\text { Economic } \\
\text { information }\end{array}$} & \multicolumn{3}{|c|}{ Frequency $(n=215)$} & \multirow[b]{2}{*}{ Total } & \multirow[b]{2}{*}{$\%$} \\
\hline & $\begin{array}{c}\text { Nueva } \\
\text { Vizcaya }\end{array}$ & Quezon & Benguet & & \\
\hline \multicolumn{6}{|c|}{ Sources of household income } \\
\hline Farming & 43 & 37 & 27 & 107 & 50.00 \\
\hline Off-farm activities & 1 & 0 & 0 & 1 & 0.50 \\
\hline Non-farm activities & 5 & 0 & 0 & 5 & 2.30 \\
\hline Farming+off-farm & 14 & 1 & 35 & 50 & 23.00 \\
\hline Farming+non-farm & 10 & 5 & 19 & 34 & 16.00 \\
\hline $\begin{array}{l}\text { Farming+off- } \\
\text { farm+non-farm }\end{array}$ & 4 & 7 & 7 & 18 & 8.00 \\
\hline \multicolumn{6}{|c|}{ Estimated annual farm income (in Peso) } \\
\hline$<10000$ & 24 & 3 & 9 & 36 & 17.00 \\
\hline $10000-20000$ & 25 & 16 & 31 & 72 & 33.00 \\
\hline $21000-30000$ & 15 & 8 & 20 & 43 & 20.00 \\
\hline $31000-40000$ & 1 & 4 & 12 & 17 & 8.00 \\
\hline $41000-50000$ & 6 & 13 & 8 & 27 & 13.00 \\
\hline $51000-60000$ & 1 & 4 & 5 & 10 & 5.00 \\
\hline $61000-70000$ & 1 & 1 & 2 & 4 & 2.00 \\
\hline $71000-80000$ & 0 & 0 & 1 & 1 & 0.50 \\
\hline $81000-90000$ & 0 & 0 & 1 & 1 & 0.50 \\
\hline$>90000$ & 3 & 1 & 0 & 4 & 2.00 \\
\hline \multicolumn{6}{|l|}{ Farm size } \\
\hline$<1$ hectare & 36 & 12 & 56 & 104 & 48.00 \\
\hline $1-3$ & 38 & 36 & 32 & 106 & 49.00 \\
\hline $3.1-5$ & 2 & 1 & 0 & 3 & 1.00 \\
\hline$>5$ & 0 & 1 & 1 & 2 & 1.00 \\
\hline \multicolumn{6}{|c|}{ Number of household members involved in farming } \\
\hline $1-3$ & 49 & 43 & 79 & 171 & 80.00 \\
\hline $4-6$ & 12 & 6 & 10 & 28 & 13.00 \\
\hline$>6$ & 15 & 1 & 0 & 16 & 7.00 \\
\hline
\end{tabular}

Table 4 summarizes economic information gathered from the farmer respondents. It shows that farming was the sole source of income of 50 percent of the respondents; meanwhile, the other half also depended on farming for livelihood, but mixed with either on-farm or off-farm sources of income, or both. Additional off-farm sources of income might have been a necessity due to the low estimated annual income that most of the respondents get from farming alone, which was less than PHP 20,000 (Php 47.49=1USD;

http:

//www.bsp.gov.ph/statistics/spei_new/tab12_pus.htm) for 50 percent of the respondents. Moreover, the relatively low income that the upland farmers derive from agricultural production might have been brought about by the limited size of the farms that they cultivate, since almost all of the respondents were smallholder farmers cultivating only three hectares of land or less $(98 \%)$.

\section{Key features of upland farms in the three study sites}

Upland farms in the Philippines are often characterized as marginal and vulnerable. This is reflected in this study, which revealed that most of the farms being cultivated by the respondents have either steep $(42 \%)$ or rolling $(41 \%)$ slopes (Table 5). These areas are vulnerable to soil erosion brought about by heavy rains and strong winds, particularly in farms with no vegetative or structural soil and water conservation measures. This vulnerability is compounded by the fact that upland farms are not usually connected to formal irrigation services. Rainfed farms are more vulnerable to changing and erratic rainfall patterns since the timing of land preparation and cultivation are dictated primarily by rainfall, making farmers more vulnerable to impacts of climate change. In the study sites, the most common water sources are springs near their farms (42\%), which highlights the need to protect and conserve the watershed in these areas to ensure continuous water supply.

It is good to note, however, that despite the limited farm sizes, farmer-respondents were able to maximize the use of their land by engaging in farm diversification, primarily through agroforestry (50\%), as well as multiple cropping (26\%) (Table 6). As discussed earlier, agroforestry is the combined production of annual crops and woody perennials and/or livestock in the same unit of land, with the twin purpose of socioeconomic productivity and ecological stability. Therefore, it is not surprising that the most common farm components were fruit trees $(26 \%)$, vegetables $(22 \%)$, and livestock $(23 \%)$. In addition, forest trees, cereals, and root crops are also cultivated in the study sites. Cereals, particularly rice (Oryza sativa), are primarily produced for home consumption, while vegetables and fruits are mainly intended for marketing.

\section{Agroforestry systems in the three study sites}

Vegetables are the most common crops in Masoc, Nueva Vizcaya, specifically baguio beans (Phaseolus vulgaris), pechay (Brassica antiquorum), tomato (Lycopersicon esculentum), and cucumbers (Cucumis sativus). In addition, farmers also cultivate cereals, such as rice (Oryza sativa) and corn (Zea mays), and root crops like ginger (Zingiber officinale), cassava (Manihot esculenta), and sweet potato (Ipomoea batatas) as mentioned earlier in Table 5. More than other cropping systems, agroforestry was widely practiced by 64 percent of the respondents. The FGD also revealed that there are four major agroforestry systems present in this upland community: the fallow system, alley cropping, contour planting, boundary planting, and fruit-tree based agroforestry.

It is interesting to note that farmers, who have bigger landholdings, practice the fallow system, as indicated in the FGD results. Since they have enough area for cultivation, part of their land can be left to rest to regain soil fertility and be used for livestock grazing. Some farmers also integrate fishponds in their farms as additional food and income sources. As shown in Figure 2, the common tree species used as live fences in boundary planting are mahogany (Swietenia macrophylla), gmelina (Gmelina arborea), and ipil-ipil (Leucaena leucocephala). These trees also serve as windbreaks that protect crops from strong winds. Likewise, the fruit trees that are usually cultivated in the farms are high-value crops, specifically, jackfruit (Artocarpus heterophyllus), rambutan (Nephelium lappaceum), lanzones (Lansium domesticum), papaya (Carica papaya), coconut (Cocos nucifera), santol (Sandoricum koetjape), banana (Musa spp.), and mango (Mangifera indica). 


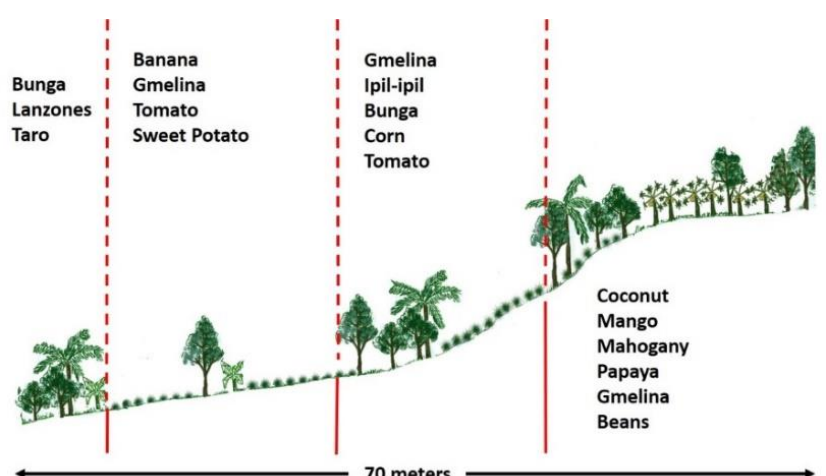

Figure 2. Transect map of selected agroforestry landscape in Barangay Masoc, Bayombong, Nueva Vizcaya

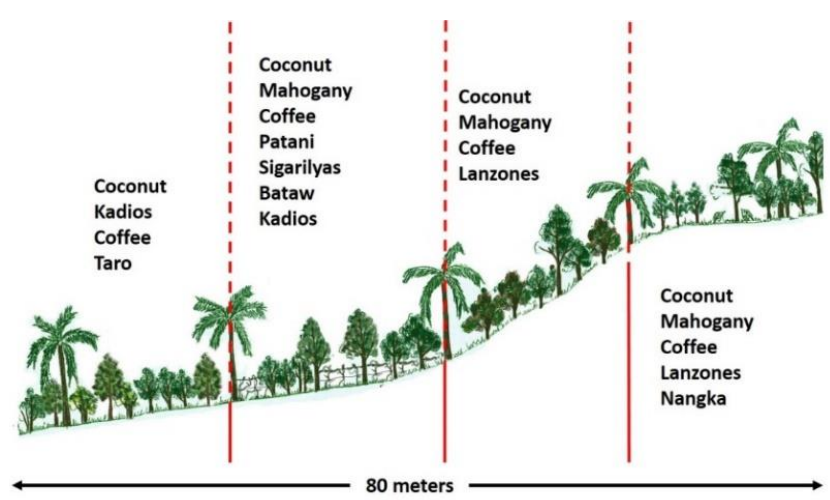

Figure 3. Transect map of selected agroforestry landscape in Barangay Concepcion Banahaw, Sariaya, Quezon

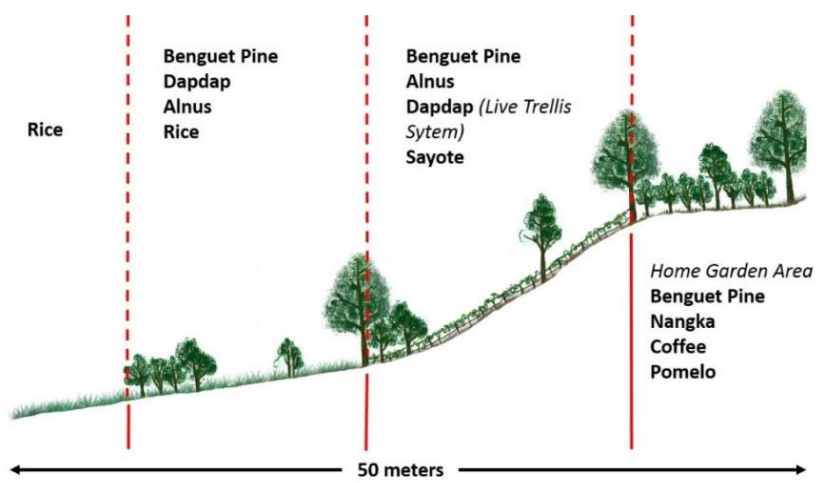

Figure 4. Transect map of selected agroforestry landscape in Barangay Ba-ayan, Tublay, Benguet.

The prevailing farming system in Concepcion is vegetable-based agroforestry integrated with fruit and forest trees, regardless of elevation (Figure 3). However, elevation does come into play in terms of what vegetables are grown by the farmers. Farmers in higher elevation cultivate carrots (Daucus carota), cabbage (Brassica oleracea), and other high-value vegetables, while bottle gourd (Lagenaria siceraria), bitter gourd (Momordica charantia), pole sitao (Vigna sesquipedalis), lima bean (Phaseolus lunatus L), and pigeon pea (Cajanus cajan) are cultivated in lower elevations. Aside from fruit and forest trees, farmers are also able to utilize the existing coconut and coffee plantation in their barangay as the foundation of their balag or trellis system.

Depending on farm elevation, upland farmers in Baayan practice either coffee-, vegetable-, or rice and vegetable-based agroforestry systems. For instance, rice and vegetable-based agroforestry is normally practiced in farms at lower elevations and with potential sources of water for irrigation (Figure 4). On the other hand, those in higher elevations are engaged in vegetable-based (particularly chayote (Sechium edule)) and coffee-based agroforestry systems. Regardless of elevation, however, farmers grow multiple crops to enable them to meet their food and income needs throughout the year.

\section{Agrobiodiversity assessment of agroforestry systems in the study sites \\ Biological diversity or biodiversity is defined as the} variability of living organisms within a boundary (GIZ 2011). Part of biodiversity is agrobiodiversity, which covers the species and their ecosystems that are used for agriculture. Thrupp (2000) enumerates the types of biological resources tied to agriculture, which include genetic resources, essential living materials of plants and animals, edible plants and crops, livestock and freshwater fish, soil organisms, naturally occurring insects, bacteria and fungi that control insect pests and diseases, and wild resources of natural habitats and landscapes. This study looked into the agrobiodiversity of the study sites with emphasis on the floral components. General species composition. The number of taxonomic families, species, and individuals found across the sampling plots established in the three study sites are summarized in Table 7.

The number of families recorded in Ba-ayan was the highest with a total of 19 , while Masoc and Concepcion Banahaw had a total of 15 and 14 taxonomic families, respectively. The common taxonomic families identified in the sampling plots included Fabaceae, Moraceae, Lamiaceae, Myrtaceae, Meliaceae, Anacardiaceae, Musaceae, and Arecaceae. In terms of number of species, the highest number was recorded in Ba-ayan with a total of 30 species, followed by Masoc (22) and Concepcion Banahaw (20). Similarly, the highest number of individuals was found in Ba-ayan (368), and only 207 were identified in Masoc and 273 in Concepcion Banahaw. A total of 50 species with at least $5 \mathrm{~cm}$ DBH were identified across the sampling plots in the three study sites. The complete list of species and families recorded are presented in Table S1.

\section{Importance Value (IV) of plant species in various agroforestry systems}

The dominant species in the three study sites include forest trees, fruit trees, and plantation crops, such as coconut and coffee (Table 9). In the case of Concepcion Banahaw, the most dominant species found was coconut, with an IV of 91.79 percent. This can be attributed to the traditional coconut-based agroforestry system practiced in the area. Mango (IV=64.13\%) was the most dominant in Masoc as the fruit tree is usually integrated into their home 
gardens and production farms. On the other hand, banana $(\mathrm{IV}=39.21 \%$ ) was found to be the most dominant species in Ba-ayan. According to the local farmers, banana has always been part of their production system because it is traditionally a local staple food. It was noted that banana, mango, and jackfruit were the dominant species consistently found across the three study sites.

The number of families recorded in Ba-ayan was the highest with a total of 19 , while Masoc and Concepcion Banahaw had a total of 15 and 14 taxonomic families, respectively. The common taxonomic families identified in the sampling plots included Fabaceae, Moraceae, Lamiaceae, Myrtaceae, Meliaceae, Anacardiaceae, Musaceae, and Arecaceae. In terms of number of species, the highest number was recorded in Ba-ayan with a total of 30 species, followed by Masoc (22 species) and Concepcion Banahaw (20 species). Similarly, the highest number of individuals was found in Ba-ayan (368), and only 207 were identified in Masoc and 273 in Concepcion Banahaw. A total of 50 species with at least $5 \mathrm{~cm} \mathrm{DBH}$ were identified across the sampling plots in the three study sites. The complete list of species and families recorded are presented in Table $\mathrm{S} 1$.

\section{Diversity and evenness indices of different agroforestry systems In the three upland sites}

The diversity and evenness indices were computed only for perennial components in the agroforestry systems. The values of Shannon-Wiener diversity index ranged from 2.21 to 2.71, with the value from Ba-ayan being the highes (Table 9). On the other hand, the evenness index values ranged from 0.40 to 0.46 . Using the classification scheme proposed by Fernando (1998), the diversity of the agroforestry systems in three study sites was considered to be low to moderate. These values indicated that practicing agroforestry can really enhance the biodiversity of a farming landscape compared to monoculture plantations. A study of Tulod et al (2017) revealed that plantations of Mahogany (Swietenia macrophylla) and Mangium (Acacia mangium) in Southern Philippines have diversity indices of 0.32 and 0.79 , respectively, which are far below from the values recorded. This could indicate that there is room for improving the present agroforestry practices into more diverse systems. Meanwhile, the low values of the evenness index, which were less than 50 percent, indicate that the individuals of each species in the agroforestry landscapes were not evenly distributed.

\section{Understorey vegetation}

A total of 14 species were found under the different agroforestry systems in three sites. There were 9 understorey species in Masoc, 5 in Ba-ayan, and 8 in Concepcion (Table S2). These understorey plants included pioneer forest tree species, timber, fruit trees, non-woody perennials, and agricultural crops being cultivated by the farmers.

\section{Tree canopy coverage of agroforestry systems}

The canopy coverage in the sampled agroforestry systems ranged from 0.00 to $368.53 \mathrm{~m}^{2}$ (Table 11). The agroforestry systems in Concepcion Banahaw obtained the lowest coverage with a mean total value of 9.36 percent, followed by Masoc (54.23\%), while Ba-ayan had the highest coverage with a mean total value of 64.78 percent. The variation can be attributed to the different agroforestry systems being practiced in each area. For example, farmers in Sariaya, Quezon opt to use light crowned trees to allow more light for their vegetable crops underneath, while also cultivating trees in the boundary. In Bayombong, Nueva Vizcaya and Tublay, Benguet, farmers plant more trees in their farms as they believe the trees can help provide favorable environmental conditions.

\section{Carbon stock assessment of agroforestry systems in the three study sites}

Biomass of agroforestry systems

The overall biomass was highest in agroforestry systems found in Masoc with a mean total of 127.00 tons $\mathrm{ha}^{-1}$, followed by Concepcion Banahaw (117.67 tons ha-1), and lowest in Ba-ayan (106.22 tons ha ${ }^{-1}$ ) (Table 12). In terms of percent contribution to biomass, the same trend was observed across the three study sites where the aboveground biomass of trees and other perennials had the highest contribution at about 85 percent, followed by the below-ground biomass of trees, while that of litter and herbaceous/understorey vegetation contributed very little at less than 1 percent. This trend mirrors the results of a carbon pool assessment of agroforestry systems in Bukidnon by Lebata et al. (2012).

In addition, the biomass of agroforestry systems across the three sites varied considerably in all carbon pools as indicated by the high standard deviation values. These variations can be attributed to the differences in the components and structures of agroforestry systems. For instance, among farmers who grow fruit trees as the main crop, some may plant additional forest trees as boundary, thereby increasing the biomass, while others do not. At the same time, individual farming practices such as weeding and burning also influence the amount of biomass of the litter and herbaceous/understorey vegetation. It is worth noting that the mean of biomass in all the study sites was higher than that of agroforestry in the Philippines, which stands at 102.80 tons $\mathrm{ha}^{-1}$ as reported by Lasco and Pulhin (2003).

Table 5. Biophysical characteristics of the farms cultivated by farmer-respondents in the three study sites

\begin{tabular}{|c|c|c|c|c|c|}
\hline \multirow[b]{2}{*}{ Biophysical conditions } & \multicolumn{3}{|c|}{ Frequency $(n=215)$} & \multirow[b]{2}{*}{ Total } & \multirow[b]{2}{*}{$\%$} \\
\hline & $\begin{array}{c}\text { Nueva } \\
\text { Vizcaya }\end{array}$ & Quezon & Benguet & & \\
\hline \multicolumn{6}{|l|}{ Topography } \\
\hline Flat & 20 & 2 & 6 & 28 & 13.00 \\
\hline Rolling & 30 & 2 & 56 & 88 & 41.00 \\
\hline Steep & 26 & 46 & 27 & 99 & 46.00 \\
\hline \multicolumn{6}{|l|}{ Water source* } \\
\hline Spring & 68 & 44 & 17 & 129 & 42.00 \\
\hline River/creeks & 2 & 1 & 59 & 62 & 20.00 \\
\hline Rainfall/rainfed & 7 & 45 & 65 & 117 & 38.00 \\
\hline
\end{tabular}

Note: *multiple responses 
Table 6. Dominant agricultural production systems being employed by the farmer-respondents in the three study sites.

\begin{tabular}{|c|c|c|c|c|c|c|c|c|c|}
\hline \multirow{2}{*}{$\begin{array}{l}\text { Biophysical } \\
\text { conditions }\end{array}$} & \multicolumn{3}{|c|}{ Frequency $(n=215)$} & \multirow[b]{2}{*}{$t^{\text {Total }}$} & \multirow[b]{2}{*}{$\%$} & \multirow{2}{*}{\multicolumn{2}{|c|}{$\begin{array}{c}\text { Total } \\
\text { number of } \\
\text { families }\end{array}$}} & \multirow{2}{*}{$\begin{array}{c}\text { Total } \\
\text { number of } \\
\text { species }\end{array}$} & \multirow{2}{*}{$\begin{array}{c}\text { Total } \\
\text { number of } \\
\text { individuals }\end{array}$} \\
\hline & $\begin{array}{c}\text { Nueva } \\
\text { Vizcaya }\end{array}$ & Quezon & Benguet & & & & & & \\
\hline \multicolumn{6}{|c|}{ Agricultural production system } & Concepcion Banahaw, & 14 & 20 & 273 \\
\hline Monocropping & 3 & 2 & 10 & 15 & 7.00 & Sariaya, Quezon & & & \\
\hline Relay cropping & 8 & 4 & 3 & 15 & 7.00 & Masoc, Bayombong, & 15 & 22 & 207 \\
\hline Multiple cropping & 4 & 13 & 30 & 47 & 22.00 & Nueva Vizcaya & & & \\
\hline Agroforestry & 61 & 31 & 46 & 138 & 64.00 & $\begin{array}{l}\text { Ba-ayan, Tublay, } \\
\text { Benguet }\end{array}$ & 19 & 30 & 368 \\
\hline \multicolumn{6}{|l|}{ Farm components* } & \multirow{5}{*}{\multicolumn{4}{|c|}{$\begin{array}{l}\text { Table 9. Shannon-Wiener Diversity and Pielous Evenness Indices } \\
\text { across sampling plots in the three study sites }\end{array}$}} \\
\hline Cereals & 23 & 0 & 36 & 59 & 8.00 & & & & \\
\hline Vegetables & 67 & 29 & 66 & 162 & 22.00 & & & & \\
\hline Root crops & 23 & 5 & 15 & 43 & 6.00 & & & & \\
\hline Fruit trees & 61 & 42 & 89 & 192 & 26.00 & & & & \\
\hline Forest trees & 43 & 6 & 63 & 112 & 15.00 & \multirow{2}{*}{$\begin{array}{c}\text { Main Plot (Circular } \\
\text { Plot with } 8.9 \mathrm{~m} \\
\text { Radius } \\
\end{array}$} & & & \\
\hline Livestock & 52 & 36 & 80 & 168 & 23.00 & & Quezon & $\begin{array}{l}\text { Nueva } \\
\text { Vizcaya }\end{array}$ & Benguet \\
\hline Total & 269 & 118 & 349 & 736 & 100 & \multirow[t]{2}{*}{$\mathrm{H}^{\prime}$} & 2.21 & 2.43 & 2.71 \\
\hline \multirow{2}{*}{\multicolumn{6}{|c|}{ Note: *multiple responses }} & & (Low) & (Low) & (Moderate) \\
\hline & & & & & & $\mathrm{J}$ & 0.40 & 0.46 & 0.46 \\
\hline
\end{tabular}

Table 8. Dominant species found in the three study sites.

\begin{tabular}{|c|c|c|c|}
\hline Study site & Common name & Scientific name & $\begin{array}{c}\text { Importance value } \\
(\%)\end{array}$ \\
\hline \multirow{7}{*}{$\begin{array}{l}\text { Concepcion Banahaw, } \\
\text { Sariaya, Quezon }\end{array}$} & Coconut & Cocos nucifera & 91.79 \\
\hline & Mahogany & Swietenia macrophylla & 53.09 \\
\hline & Banana & Musa sapientum & 38.03 \\
\hline & Mango & Mangifera indica & 20.19 \\
\hline & Coffee & Coffea arabica & 19.78 \\
\hline & Jackfruit & Artocarpus heterophyllus & 18.81 \\
\hline & Kakauate & Gliricidia sepium & 16.35 \\
\hline Masoc, Bayombong, Nueva & Mango & Mangifera indica & 64.13 \\
\hline \multirow{8}{*}{ Vizcaya } & Banana & Musa sapientum & 44.30 \\
\hline & Gmelina & Gmelina arborea & 29.15 \\
\hline & Jackfruit & Artocarpus heterophyllus & 26.17 \\
\hline & Mahogany & Swietenia macrophylla & 23.76 \\
\hline & Pomelo & Citrus maxima & 21.47 \\
\hline & Tibig & Ficus nota & 15.36 \\
\hline & Avocado & Persea americana & 13.52 \\
\hline & Binunga & Macaranga tanarius & 11.13 \\
\hline \multirow[t]{8}{*}{ Ba-ayan, Tublay, Benguet } & Banana & Musa sapientum & 39.21 \\
\hline & Jackfruit & Artocarpus heterophyllus & 38.65 \\
\hline & Mango & Mangifera indica & 32.68 \\
\hline & Coffee & Coffea arabica & 31.99 \\
\hline & Pomelo & Citrus maxima & 31.57 \\
\hline & Alnus & Alnus japonica & 26.82 \\
\hline & Tuai & Bischofia javanica & 11.68 \\
\hline & Avocado & Persea americana & 10.11 \\
\hline
\end{tabular}

Table 11. Tree canopy coverage of agroforestry systems in the three study sites.

\begin{tabular}{lccccccc}
\hline \multicolumn{1}{c}{ Study site } & $\begin{array}{c}\text { No.of } \\
\text { sample } \\
\text { plots }(\mathbf{n})\end{array}$ & $\begin{array}{c}\text { Total } \\
\text { area } \\
\text { sampled } \\
\left(\mathbf{m}^{\mathbf{2}}\right)\end{array}$ & Min & Max & $\begin{array}{c}\text { Mean } \\
(\boldsymbol{\mu})\end{array}$ & SD $( \pm)$ & Total* \\
\hline Concepcion Banahaw, Sariaya, Quezon & 36 & $8,953.92$ & 0.00 & 110.26 & 23.28 & 28.34 & $715.63(9.36 \%)$ \\
Ba-ayan, Tublay, Benguet & 17 & $3,979.52$ & 59.00 & 311.74 & 154.63 & 86.73 & $2,541.53(64.78 \%)$ \\
Masoc, Bayombong, Nueva Vizcaya & 16 & $4,228.24$ & 17.89 & 368.53 & 126.53 & 112.17 & $1,808.40(54.23 \%)$ \\
\hline
\end{tabular}


Table 12. Biomass of agroforestry systems in three study sites.

\begin{tabular}{|c|c|c|c|c|c|}
\hline \multirow{3}{*}{ Item } & \multicolumn{5}{|c|}{ Biomass (tons ha-1 ) } \\
\hline & \multicolumn{3}{|c|}{ Above ground } & \multirow{2}{*}{$\begin{array}{c}\text { Below ground } \\
\text { Trees and other } \\
\text { perennials }\end{array}$} & \multirow[b]{2}{*}{$\begin{array}{c}\text { Mean } \\
\text { total }\end{array}$} \\
\hline & $\begin{array}{c}\text { Trees and other } \\
\text { perennial }\end{array}$ & Herbaceous & Litter & & \\
\hline \multicolumn{6}{|c|}{ Concepcion Banahaw, Sariaya, Quezon } \\
\hline Minimum & 4.44 & 0.25 & 0.40 & 0.67 & 117.67 \\
\hline Maximum & 452.20 & 1.10 & 1.82 & 67.83 & \\
\hline \multirow{2}{*}{$\operatorname{Mean} *(\mu)$} & 100.97 & 0.57 & 0.99 & 15.14 & \\
\hline & $(85.81 \%)$ & $(0.48 \%)$ & $(0.84 \%)$ & $(12.87 \%)$ & \\
\hline Standard Deviation $( \pm)$ & 95.43 & 0.33 & 0.58 & 14.32 & \\
\hline No. of Sample Plots (n) & 36 & 36 & 36 & 36 & \\
\hline \multicolumn{6}{|c|}{ Masoc, Bayombong, Nueva Vizcaya } \\
\hline Minimum & 2.18 & 0.16 & 0.17 & 0.33 & 127.00 \\
\hline Maximum & 283.83 & 1.25 & 1.83 & 42.57 & \\
\hline \multirow[t]{2}{*}{$\operatorname{Mean} *(\mu)$} & 109.54 & 0.53 & 0.78 & 16.15 & \\
\hline & $(86.25 \%)$ & $(0.42 \%)$ & $(0.61 \%)$ & $(12.72 \%)$ & \\
\hline Standard Deviation $( \pm)$ & 89.48 & 0.34 & 0.55 & 13.58 & \\
\hline No. of Sample Plots (n) & 17 & 17 & 17 & 17 & \\
\hline \multicolumn{6}{|l|}{ Ba-ayan, Tublay, Benguet } \\
\hline Minimum & 18.01 & 0.21 & 0.84 & 2.70 & 106.22 \\
\hline Maximum & 293.35 & 0.85 & 3.91 & 44.00 & \\
\hline & 90.17 & 0.56 & 1.96 & 13.53 & \\
\hline $\operatorname{Mean}^{*}(\mu)$ & $(84.89 \%)$ & $(0.53 \%)$ & $(1.84 \%)$ & $(12.74 \%)$ & \\
\hline Standard Deviation $( \pm)$ & 66.03 & 0.19 & 0.89 & 9.91 & \\
\hline
\end{tabular}

Table 13. Carbon stock of agroforestry systems in three study sites

\begin{tabular}{|c|c|c|c|c|c|}
\hline \multirow{3}{*}{ Item } & \multicolumn{5}{|c|}{$\begin{array}{l}\left.\text { Carbon stock (ton } \mathrm{C} \mathrm{ha}^{-1}\right) \\
\end{array}$} \\
\hline & \multicolumn{3}{|c|}{ Above ground } & \multirow{2}{*}{$\begin{array}{c}\text { Below ground } \\
\text { Trees and other perennials }\end{array}$} & \multirow{2}{*}{$\begin{array}{c}\text { Mean } \\
\text { total }\end{array}$} \\
\hline & Trees and other perennials & Herbaceous & Litter & & \\
\hline \multicolumn{6}{|c|}{ Concepcion Banahaw, Sariaya, Quezon } \\
\hline Minimum & 2.00 & 0.11 & 0.18 & 0.30 & \\
\hline Maximum & 203.49 & 0.50 & 0.82 & 30.52 & \\
\hline Mean* $(\mu)$ & $\begin{array}{l}45.43 \\
(85.78 \%)\end{array}$ & $\begin{array}{l}0.26 \\
(0.49 \%)\end{array}$ & $\begin{array}{l}0.45 \\
(0.85 \%)\end{array}$ & $\begin{array}{l}6.82 \\
(12.88 \%)\end{array}$ & 52.96 \\
\hline Standard Deviation $( \pm)$ & 42.95 & 0.15 & 0.26 & 6.44 & \\
\hline No. of Sample Plots (n) & 36 & 36 & 36 & 36 & \\
\hline \multicolumn{6}{|c|}{ Masoc, Bayombong, Nueva Vizcaya } \\
\hline Minimum & 0.98 & 0.07 & 0.08 & 0.15 & 57.15 \\
\hline Maximum & 127.72 & 0.56 & 0.83 & 19.16 & \\
\hline $\operatorname{Mean} *(\mu)$ & $\begin{array}{l}49.29 \\
(86.25 \%)\end{array}$ & $\begin{array}{l}0.24 \\
(0.42 \%)\end{array}$ & $\begin{array}{l}0.35 \\
(0.61 \%)\end{array}$ & $\begin{array}{l}7.27 \\
(12.72 \%)\end{array}$ & \\
\hline Standard Deviation $( \pm)$ & 40.26 & 0.15 & 0.25 & 6.11 & \\
\hline No. of Sample Plots (n) & 17 & 17 & 17 & 17 & \\
\hline \multicolumn{6}{|l|}{ Ba-ayan, Tublay, Benguet } \\
\hline Minimum & 8.11 & 0.09 & 0.38 & 1.22 & \\
\hline Maximum & 132.01 & 0.38 & 1.76 & 19.80 & \\
\hline $\operatorname{Mean} *(\mu)$ & $\begin{array}{l}40.58 \\
(84.90 \%)\end{array}$ & $\begin{array}{l}0.25 \\
(0.52 \%)\end{array}$ & $\begin{array}{l}0.88 \\
(1.84 \%)\end{array}$ & $\begin{array}{l}6.09 \\
(12.74 \%)\end{array}$ & 47.80 \\
\hline Standard Deviation $( \pm)$ & 29.72 & 0.08 & 0.40 & 4.46 & \\
\hline No. of Sample Plots (n) & 16 & 16 & 16 & 16 & \\
\hline
\end{tabular}

Note: * Values shown inside the parenthesis are the percentage compositions of the different carbon pools. 
Carbon stock of agroforestry systems

Parallel with the results in Table 13, the carbon stock was also highest in agroforestry systems found in Bayombong, Nueva Vizcaya with a mean total of 57.15 ton $\mathrm{C} \mathrm{ha} \mathrm{h}^{-1}$, ahead of Sariaya, Quezon (52.96 ton $\mathrm{C} \mathrm{ha}^{-1}$ ) and Tublay, Benguet (47.80 ton $\mathrm{C} \mathrm{ha}^{-1}$ ) (Table 14). These results are comparable to the overall mean of carbon stock of tree plantations (59.0 ton $\mathrm{C} \mathrm{ha}^{-1}$ ) and higher than the mean for different agroforestry systems (45.4 ton $\left.\mathrm{C} \mathrm{ha}^{-1}\right)$ in the Philippines as reported by Lasco and Pulhin (2003). Also consistent with the biomass data, the above ground carbon of trees and other perennial crops also ranked first in terms of percentage contribution $(85 \%)$, followed by below ground carbon of trees and other perennials (13\%), litter (less than 2\%), and herbaceous with less than 1 percent. It should be noted that the inclusion of the soil carbon pool could significantly increase the carbon stock due to high concentration of carbon in the soil. According to a study by De Stefano and Jacobson (2018), shifting from agriculture to agroforestry significantly increased soil organic carbon by $34 \%$ on average. As noted by Nair (2009), besides storing important amounts of carbon aboveground biomass, trees and shrubs can store greater amounts of carbon in belowground biomass. Therefore, incorporating trees and shrubs into agroforestry systems (AFS) can markedly increase carbon sequestration compared with other systems like monoculture pastures.

In conclusion, this study revealed that agroforestry systems provide ecological contributions particularly in carbon sequestration and biodiversity conservation, and serve as food and income sources of the upland farmers. In addition, other studies show that agrobiodiversity provides ecosystem services on farms, such as pollination, fertility and nutrient enhancement, insect and disease management, and water retention. It is, therefore, necessary to intensify agroforestry promotion within farming communities in the Philippines and in developing countries with similar conditions, to address sustainable development. Expansion of agroforestry should take place in the rehabilitation of degraded areas and not on existing forests, especially in very important upland watershed areas.

\section{ACKNOWLEDGEMENTS}

The authors acknowledge the Southeast Asia Regional Center for Graduate Study in Agriculture (SEARCA), the collaborating state colleges and universities- Benguet State University (BSU) and Nueva Vizcaya State University (NVSU) and the farmer-respondents in Barangay Baayan, Tublay, Benguet; and, Barangay Masoc, Bayombong, Nueva Vizcaya.

\section{REFERENCES}

Brown S. 1997. Estimating Biomass and Biomass Change of Tropical Torest: A Primer. FAO. Forestry Paper 134. FAO. Rome, Italy.

De Stefano A, Jacobson MG 2018. Soil carbon sequestration in agroforestry systems: a meta-analysis. Agrofor Syst 92: 285-299. DOI: $10.1007 / \mathrm{s} 10457-017-0147-9$

Doney SC, Schimel DS. 2007: Carbon and climate system coupling on timescales from the Precambrian to the Anthropocene, Ann. Rev. Environ. Resour 32: 31-66. DOI: 10.1146/annurev.energy.32.041706.124700.

Fernando ES 1998. Forest formations and flora of the Philippines: Handout in FBS 21. UPLB, Philippines.

Jose, S. (2009. Agroforestry for ecosystem services and environmental benefits: an overview. Agroforest Syst 76: 1-10. DOI 10.1007/s10457-009-9229-7.

Landicho, LD, Visco RG, Paelmo RF, Cabahug RD, Baliton RS, Espaldon MO, Lasco RD. 2015. Field-level evidences of climate change and adaptation strategies of smallholder farmers in Molawin-Dampalit Sub-Watershed, Makiling Forest Reserve. Asian J Agric Dev 12 (2): $81-94$

Lasco RD, Pulhin FB. 2003. Philippine forest ecosystems and climate change: carbon stocks, rate of sequestration and the Kyoto Protocol. Ann Trop Res 25 (2): 37-51.

Lebata MM, Aranico EC, Tabaranza ACE, Patricio JHP, Amparado RFJr. 2012. Carbon stock assessment of three selected agroforestry systems in Bukidnon, Philippines. Adv Environ Sci 4 (1): 5-11.

Lundgren BO, Raintree JB. 1983. Sustained agroforestry. In: Nestal B (ed.) Agricultural Research for Development: Potentials and Challenges in Asia. International Service for National Agricultural Research (ISNAR), The Hague.

Thrupp LA. 2000. Linking agricultural biodiversity and food security: The valuable role of agrobiodiversity for sustainable agriculture. Intl Affairs 76 (2): 265-28I.

Tolentino LL, Landicho LD, de Luna CC, Cabahug RD. 2010. Case study: agroforestry in the Philippines. Routledge Publishing, UK

Tulod AM, Casas JV, Marin RA, Ejoc JAB. 2017. Diversity of native woody regenerations in exotic and natural forest in Southern Philippines. For Sci Technol 13 (1): 13-40.

Visco, RG, Landicho LD, Paelmo RF, Cabahug RED, Baliton RS. 2012. Assessment of local adaptive strategies and role of trees in climate change adaptation in Wahig-Inabanga Watershed. Project Report submitted to the World Agroforestry Centre-Philippine Office. UPLB, College, Laguna

World Agroforestry Centre. 2007. Agroforestry science at the heart of the three environemental conventions. Annual Report for 2006. World Agroforestry Centre (ICRAF). Nairobi, Kenya. 
Table S1. Complete list of species identified across sampling plots in three study sites

\begin{tabular}{|c|c|c|}
\hline $\begin{array}{l}\text { Common } \\
\text { name }\end{array}$ & Scientific name & Family name \\
\hline Achuete & Bixa orellana & Bixaceae \\
\hline Alim & Melanolepis multiglandulosa & Euphorbiaceae \\
\hline Alnus & Alnus japonica & Betulaceae \\
\hline Aratiles & Muntigia calabura & Muntigeacea \\
\hline Aunasin & Ardisia pyramidalis & Myrsinaceae \\
\hline Avocado & Persea americana & Lauraceae \\
\hline Banana & Musa sapientum & Musaceae \\
\hline Banuyo & Wallaceodendron celebicum & Fabaceae \\
\hline Bayabas & Psidium guajava & Myrtaceae \\
\hline Binunga & Macaranga tanarius & Euphorbiaceae \\
\hline Bunga & Areca catechu & Arecaceae \\
\hline Cacao & Theobroma cacao & Malvaceae \\
\hline Caimito & Chrysophyllum cainito & Sapotaceae \\
\hline Coffee & Coffea arabica & Rubiaceae \\
\hline Coconut & Cocos nucifera & Arecaceae \\
\hline Dalandan & Citrus aurantium & Rutaceae \\
\hline Dapdap & Erythrina variegata & Fabaceae \\
\hline Eucalyptus & Eucalyptus deglupta & Myrtaceae \\
\hline Fire Tree & Delonix regia & Fabaceae \\
\hline Gmelina & Gmelina arborea & Lamiaceae \\
\hline Gov. Plum & Flacourtia jangomas & Salicaceae \\
\hline Guyabano & Annona muricata & Annonaceae \\
\hline Hauili & Ficus leucopleura F. Vill & Moraceae \\
\hline Ipil-ipil & Leucaena leucocephala & Fabaceae \\
\hline Kakauate & Gliricidia sepium & Fabaceae \\
\hline Kalamansi & Citrofortunella microcarpa & Rutaceae \\
\hline Kamias & Averrhoa bilimbi & Oxalidaceae \\
\hline Katmon & Dillenia philippinensis & Dilleniaceae \\
\hline Lamog & Planchonia spectabilis & Lecythidaceae \\
\hline Lanzones & Lansium domesticum & Meliaceae \\
\hline Longgan & Dimocarpus longan & Sapindaceae \\
\hline Magabuyo & Celtis luzonica & Cannabaceae \\
\hline Mahogany & Swietennia macrophylla & Meliaceae \\
\hline Malungai & Moringa oleifera & Moringaceae \\
\hline Mangga & Mangifera indica & Anacardiaceae \\
\hline Mangium & Acacia mangium & Fabaceae \\
\hline Manila palm & Adonidia merrillii & Arecaceae \\
\hline Marang & Artocarpus odoratissimus & Moraceae \\
\hline Misc 1 Rubia & Rubia sp. & Rubiaceae \\
\hline Misc 2 Mora & Ficus sp. & Moraceae \\
\hline Jackfruit & Artocarpus heterophyllus & Moraceae \\
\hline Pomelo & Citrus maxima & Rutaceae \\
\hline Rambutan & Nephelium lappaceum & Sapindaceae \\
\hline Santol & Sandoricum koetjape & Meliaceae \\
\hline Spanish & Psidium sp. & Myrtaceae \\
\hline \multicolumn{3}{|l|}{ Guava } \\
\hline Taluto & Pterocymbium tinctorium & Malvaceae \\
\hline Tibig & Ficus nota & Moraceae \\
\hline Tiesa & Pouteria rivicoa & Sapotaceae \\
\hline Tuai & Bischofia javanica & Phyllanthaceae \\
\hline Upling & Ficus ampelas & Moraceae \\
\hline Gubat & & \\
\hline
\end{tabular}

Table S2. List of understorey vegetation identified in three study sites

\begin{tabular}{lll}
\hline $\begin{array}{l}\text { Common } \\
\text { name }\end{array}$ & Scientific name & Family name \\
\hline Masoc, Bayombong, Nueva Vizcaya & Melanolepis \\
& multiglandulosa & \\
Alim & Macaranga tanarius & Euphorbiaceae \\
Binunga & Ficus leucopleura & Moraceae \\
Hauili & Leucaena leucocephala & Fabaceae \\
Ipil-ipil & Swietennia macrophylla & Meliaceae \\
Mahogany & Artocarpus heterophyllus & Moraceae \\
Jackfruit & Ficus nota & Moraceae \\
Tibig & Bischofia javanica & Phyllanthaceae \\
Tuai & Ficus ampelas & Moraceae \\
UplingGubat
\end{tabular}

Ba-ayan, Tublay, Benguet

Binunga Macarangatanarius Euphorbiaceae

Hauili Ficus septica Moraceae

Tibig Ficus nota Moraceae

Tuai Bischofia javanica Phyllanthaceae

UplingGubat Ficus ampelas Moraceae

Concepcion Banahaw, Sariaya, Quezon

Winged Bean Psophocarpus tetragonolobus Fabaceae

Pigeon Pea Cajanus cajan Fabaceae

Cassava Manihot esculenta Euphorbiaceae

Lima bean Phaseolus lunatus Fabaceae

Bataw Dolichos lablab Fabaceae

Mahogany Swietennia macrophylla Meliaceae

Ipil-ipil Leucaena leucocephala Fabaceae

Tibig Ficus nota Moraceae 